\title{
Feline immunodeficiency virus latency
}

\author{
Samantha J McDonnel ${ }^{1,3^{*}}$, Ellen E Sparger ${ }^{2}$ and Brian G Murphy ${ }^{1}$
}

\begin{abstract}
Despite highly effective anti-retroviral therapy, HIV is thought to persist in patients within long-lived cellular reservoirs in the form of a transcriptionally inactive (latent) integrated provirus. Lentiviral latency has therefore come to the forefront of the discussion on the possibility of a cure for HIV infection in humans. Animal models of lentiviral latency provide an essential tool to study mechanisms of latency and therapeutic manipulation. Of the three animal models that have been described, the feline immunodeficiency virus (FIV)-infected cat is the most recent and least characterized. However, several aspects of this model make it attractive for latency research, and it may be complementary to other model systems. This article reviews what is known about FIV latency and chronic FIV infection and how it compares with that of other lentiviruses. It thereby offers a framework for the usefulness of this model in future research aimed at lentiviral eradication.
\end{abstract}

Keywords: FIV, Latency, HIV-1, Feline, Animal model, Antilatency therapy, Reservoir

\section{Review} Introduction

It was estimated that 34 million people worldwide were living with HIV/AIDS as of 2011, more than 1 million of whom were living in the United States [1]. While advancements made in highly active antiretroviral therapy (HAART) have dramatically increased survival time and quality of life for those infected with HIV, long term treatment is problematic for several reasons [2]. Among them are the necessity of life-long adherence to medication regimens, the potential for cumulative side-effects, emergence of drug-resistant mutants, and the unbearable cost for the majority of the world's HIV-infected individuals [3,4]. In people undergoing HAART, viremia is typically reduced to less than 50 copies of HIV RNA per milliliter of blood [5]. Unfortunately, drug withdrawal generally results in rebound viremia, with subsequent progression to clinical AIDS [6]. It has been hypothesized that HIV is able to persist through both ongoing, low-level replication and as a transcriptionally inactive (latent) integrated provirus [7]. Studies demonstrating a lack of viral genetic evolution support the latter hypothesis, suggesting that cellular latency may be the cause of viral rebound [8], and memory

\footnotetext{
* Correspondence: sjmcdonnel@ucdavis.edu

'Department of Pathology, Microbiology \& Immunology, School of Veterinary Medicine, University of California, Davis, 4206 Vet Med 3A, Davis, CA 95616, USA ${ }^{3}$ VetMed PMI, 4206 VetMed 3A, One Shields Avenue, Davis, CA 95616-5270, USA Full list of author information is available at the end of the article
}

CD4+ T cells are thought to be the primary long-lived reservoirs [9].

The concept of lentiviral latency has therefore come to the forefront of the discussion on the possibility of a cure for HIV infection in humans. For the purposes of this discussion, lentiviral cellular latency is defined as the presence of proviral DNA (integrated or episomal) in the absence of detectable viral RNA (vRNA) transcripts. Of course, such a definition is only meaningful in the context of highly sensitive real-time PCR assays as the inability to detect vRNA is not necessarily the same as a truly negative result. Cellular latency is distinct from clinical latency in that it describes the viral activity or inactivity within a single cell, rather than the collective manifestation of viral replication in the host as a whole. Latently-infected cells have been found to naturally occur in all three immunodeficiency-causing lentivirus infections [HIV, simian immunodeficiency virus (SIV), and feline immunodeficiency virus (FIV)] within their respective hosts [7,10-12]. Because latently-infected cells do not contain detectable viral RNA or protein, they go largely undetected by the host's immune system. In addition, latent provirus is not affected by antiretroviral therapy (ART), which serves to impede only ongoing rounds of viral replication by inhibiting various viral enzymes or cellular entry mechanisms. Thus, the latentlyinfected cell population serves as reservoir for the persistence of HIV despite the presence of ongoing ART and

\section{Biomed Central}

(C) 2013 McDonnel et al.; licensee BioMed Central Ltd. This is an Open Access article distributed under the terms of the Creative Commons Attribution License (http://creativecommons.org/licenses/by/2.0), which permits unrestricted use, distribution, and reproduction in any medium, provided the original work is properly cited. 
represents the major barrier to viral eradication (cure) from the host $[11,13,14]$.

Multiple molecular mechanisms may underlie the establishment and maintenance of latent cellular reservoirs including availability of transcription and nuclear export factors, the viral integration locus, RNA interference (RNAi), transcriptional interference, and epigenetic modifications of proviral DNA or histone proteins in the local chromatin environment [15-22]. It is thought that latentlyinfected cells, which are established within the first several days of infection, are stochastically (randomly) reactivated to resume viral transcription, translation, and virion assembly [20]. In the ART-treated individual, the likelihood that virions produced from transcriptionally reactivated cells will infect new cells is very low due to the constant presence of ART drugs in circulation. But in most cases upon removal of ART from an HIV-infected individual, viremia rapidly rebounds and causes an eventual progression to AIDS $[11,14]$. Thus understanding of how viral latency is established and maintained, and perhaps even more importantly, how it can be manipulated, is of great importance to viral eradication efforts. And if therapy to reverse viral latency (so-called anti-latency therapy, or ALT) is possible, it would be prudent to test this therapy in an animal model of lentiviral latency due to both apparent and inapparent risks involved with viral reactivation in an individual who is well controlled on ART. Therefore, animal models of lentiviral latency provide an essential tool to study mechanisms of latency and therapeutic manipulation. Three in vivo animal models of lentiviral latency exist today: the SIV-infected macaque, the HIV-infected humanized mouse, and most recently, the FIV-infected cat. This review seeks to describe what is known about FIV latency and how it compares with that of other lentiviruses, as well as provide a framework for the usefulness of this model in research aimed at lentiviral eradication.

\section{Current models of HIV latency}

Each model of lentiviral latency has both distinct benefits and drawbacks [23]. The plethora of in vitro cell-line models of CD4+ T-cell latency have been instrumental in both mechanistic studies and in the screening of new classes of viral eradication drugs [24]. However, it is unclear how similar these proliferating cells are to the primary in vivo reservoir of resting/memory cells. In addition, since these models are often established by a single latently infected cell (i.e., a clonal population), they may not reflect the heterogeneity of the latent reservoir in the host. Primary cell models have also been established which may more closely reflect HIV latency in vivo [25], but they are limited by their somewhat contrived induction. Latentlyinfected cells isolated from HIV-infected individuals and analyzed ex vivo may be the most reliable of the "in vitro" models, but they are more difficult to obtain in sufficient numbers (often requiring leukapheresis) and are still assessed in isolation from the immune system and in vivo environment. Animal models of lentiviral latency have therefore garnered much interest for investigations into the location and nature of viral reservoirs and potential induction therapy.

Humanized mouse models of HIV infection, based on engraftment of human cells and tissue into recipient immunocompromised mice, are undoubtedly the most tractable and versatile in vivo model. All of the benefits of using mice (cost, genetic traceability, and availability of reagents, among others), in addition to the fact that this model employs HIV-1 rather than another lentivirus, make it an attractive model for latency [26]. On the other hand, accurately modeling an infection that is so intricately related to the intact immune system is difficult in an incomplete or immunocompromised background. In addition, the inbred nature and non-natural host aspects of mouse models may be considered a disadvantage. The SIV-infected macaque, on the other hand, represents an outbred, large-animal model with a natural physiology close to that of humans. Using infected macaques treated with HAART regimens, SIV latency has been observed in peripheral blood, the central nervous system [27], and various lymphoid tissues [12], making this a strong model to study viral reservoirs that persist during therapy. However, nonhuman primate studies are expensive and timeconsuming, and while HIV remains latent in humans for several years, this phase is abbreviated to several months in macaques [23]. The macaque monkey is also not a natural host of SIV. Like SIV, FIV represents an outbred, large animal model which is still experimentally tractable. In contrast, while SIV has greater genetic similarity to HIV, FIV infection in cats is the only case (other than HIV) of an immunodeficiency-causing lentiviral infection in its natural host. And unlike macaques, transgenic cats are becoming available for lentivirus-related research [28]. The cost and difficulty of using cats in research is much less compared to nonhuman primates. Given the complexity of the problem and the various strengths and weaknesses of each model, it may be concluded that each of these models, both in vitro and in vivo, have a role to play in the study of lentiviral latency, reservoirs, and eradication strategies.

\section{The FIV model of HIV infection}

FIV was first isolated and described in 1986 from domestic cats with immunodeficiency-like syndromes in a northern California cattery [29]. The five major subtypes (clades) of FIV are designated A through E, and each has a particular geographic distribution throughout the world [30]. FIV is similar to HIV in genome structure and immunopathogenesis [31,32], and has been utilized as the only naturally-occurring animal 
model of immunodeficiency for HIV-infection in people [33]. Acute FIV infection results in flu-like symptoms including peripheral lymphadenopathy, neutropenia, and pyrexia [34-36]. During terminal stages of infection, animals exhibit feline acquired immunodeficiency syndrome (FAIDS), which includes opportunistic infections, lymphomas, wasting, and death [37]. As in HIV infection, there is typically a protracted asymptomatic phase lasting at least several years prior to the terminal immunodeficiency syndrome. Despite a lack of clinical signs, there is evidence of immunological impairment (CD4+ T cell depletion and $\mathrm{CD} 4 / \mathrm{CD} 8$ ratio inversion) during the asymptomatic phase $[38,39]$.

The genomes of FIV and HIV-1 (the predominant subtype of HIV) encode the same three main genes found in all retroviruses: 'group-specific antigen' (gag), polymerase $(p o l)$, and envelope (env), in addition to the lentivirusspecific accessory genes 'viral infectivity factor' (vif) and 'regulator of virion expression' (rev). HIV-1 encodes four additional accessory proteins not found in FIV: tat, $v p r$, $v p u$, and $n e f$. FIV does however encode a unique accessory gene known as orf- $A$, thought to have functional overlap with $v p r, v p u$, and $n e f[40,41]$. Importantly, the orf- $A$ protein has not been shown to have significant transcriptional transactivating activity like HIV tat [42], and FIV is not known to encode any such transcriptional transactivator. In addition to genomic differences, the cellular tropism of FIV is generally thought to be broader than that of HIV as it includes all major subsets of mononuclear leukocytes [34]. However, both FIV and HIV have been shown to infect CD8+ T cells and B cells in addition to the CD4+ T cells and monocytes/macrophages, which are the primary permissive cell types in vivo [43-49]. Both viruses have also been reported to infect microglia, astrocytes, and various other cell types to a lesser extent [34]. The primary cellular receptors used by these lentiviruses are CD4 and CD134 for HIV-1 and FIV respectively [50-53]. Both viruses may use the chemokine receptor CXCR4, and HIV-1 can additionally use CCR5 as a co-receptor [54-57].

Despite intensive study since its discovery over 27 years ago, relatively little has been published on FIV in the chronic/asymptomatic, or even terminal FAIDS stages of disease. The vast majority of experimental FIV research has focused on acute FIV infection, with most studies terminating at or before 6 months post infection. This is in large part due to initial enthusiasm for FIV infection as a model for vaccine development and early immunopathogenesis $[33,58]$, as well as the cost associated with long-term studies. As a result, relatively little is known about virological parameters during chronic FIV infection under experimentally controlled conditions. In naturally-infected cats, plasma viral RNA load has been shown to correlate with the clinical stage, survival time, and disease progression [59]. Similar to acute HIV infection, experimental FIV infection causes an initial undulating viremia lasting four to six months [10,31,34]. Diehl et al. described a decrease in plasma viremia after approximately 10 weeks of FIV-B infection, though it remained significant and detectable $\left(\sim 10^{5}\right.$ copies $/ \mathrm{mL}$ ) until the end of the study period (36 weeks) [60]. The same group developed a model of rapid FAIDS progression by acute-phase FIV-C passage [61], and demonstrated with this accelerated model of pathogenesis that plasma viremia is predictive of FIV disease progression [62]. Miller and Fogle reported detectable viremia at 1, 2, and 3 years post infection with FIV-A [63]. Another study by Miller et al. found cell-free virus in cerebrospinal fluid and neural tissue at 350 days post intravenous infection with FIV-A, C, and an A/C chimeric virus [64]. Freer et al. reported stable, moderate plasma viremia and PBMC proviral burden after 1 to 7 years of experimental infection with FIV-B [65]. Kraase et al. found variably detectable proviral burden in cats infected with FIV-A for 322 weeks ( $\sim 6$ years), but significantly increased viral env evolution relative to 12 weeks post infection [66], suggestive of ongoing viral replication. In two studies of FIV superinfection, viral loads in both plasma and PBMC remained detectable over 9 months [67] or three years [68] in cats infected with just one subtype, but declined significantly or was undetectable in cats pre-infected with another, attenuated or chimeric subtype. Kohmoto et al. observed 3 experimentally FIV-infected cats over the course of 8 years, and found that the one animal that developed FAIDS had a very high plasma viral load $\left(2^{10}\right.$ titration) whereas the other two were undetectable [37]. Our research group has observed persistently undetectable plasma viremia using a sensitive realtime PCR assay after approximately 10 months of infection with FIV-C [10]. Other studies documenting the development of clinical signs and pathologic lesions after years of experimental FIV infection [69-74] have not examined plasma viremia or the status of intracellular virus replication. To summarize, plasma viremia and cellular proviral load during the chronic, asymptomatic phase of experimental FIV infection has been found to be quite variable, ranging from undetectable to $10^{5}$ copies $/ \mathrm{mL}$ or higher, which may depend on viral subtype, inoculating titer, route of inoculation, or other factors.

More attention has been paid to immunological effects of long-term FIV infection, with a particular emphasis on the hallmark CD4+ T-cell depletion and persistent CD4/CD8 ratio inversion $[38,39,75,76]$. There has also been documentation of chronic immune dysregulation $[75,77,78]$ and inadequate CD8+ T-cell antiviral function [79] in longitudinal studies. The immunophenotype of cells harboring latent FIV, which is largely uncharacterized for this virus, may affect the ability to pharmacologically reactivate latent virus. FIV has been shown to preferentially infect CD4 + CD25+ activated/regulatory T-cells (Tregs) [80], which correlates with both surface CXCR4 expression and binding of 
cellular transcription factors to the FIV promoter [81]. Feline Tregs have since been characterized using FoxP3 $[82,83]$, so these studies are merely suggestive of infection in that subset. Importantly, the FIV receptor CD134 (OX40) is constitutively expressed on Tregs [84], lending support to this hypothesis. CD4 + CD25+ and $\mathrm{CD} 4+\mathrm{CD} 25-\mathrm{T}$ cells appear to possess different activation requirements, modulated by viral titer and cytokine stimuli, to reach threshold activation levels required to harbor a productive FIV infection [85]. This holds implications for the differential ability of the two subsets to serve as potential latent reservoirs, though our research group has found both subsets to be equal in terms of latency status in the periphery during chronic FIV-C infection [10]. Finally, the ability of the immune system to adequately respond and kill reactivated cells is critical to proposed strategies to purge viral reservoirs. Selective depletion of CD4+ CD25+ cells has been shown to result in improved antiviral responses in cats chronically infected with FIV $[83,86]$, which could potentially be part of a strategy to boost the immune system during or after ALT. There is much still to be learned about these and other interactions between the immune system and latent FIV.

\section{FIV Latency}

Though the research has thus far been somewhat limited, several groups have observed FIV latency both in vitro and in vivo. Ikeda et al. demonstrated that an infectious molecular clone of FIV-Petaluma (FIV-A) was able to infect the human lymphoblastoid cell line MOLT-4 in vitro, but established a transcriptionally latent infection unless stimulated by phorbol ester [87]. The molecular mechanism of FIV latency in human cell lines has not been reported; however, this form of latency may be due to differences in species-specific viral restriction factors and corresponding viral evasion mechanisms. More recently, another group demonstrated that a cellular clone of a feline T-cell line (FeT-J) chronically infected (>50 days) with FIV-A led to a latent phenotype, which was inducible by treatment with mitogens [88]. There is also evidence that FIV can establish a latent infection in vivo following mucosal administration of low-dose cell-associated FIV-A [89], in peripheral blood CD4+ T-cells during chronic FIV-C infection [10], and in peripheral blood mononuclear cells (PBMC) during chronic FIV-B infection [90]. The later reported the presence of multiply-spliced FIV mRNA, but extremely low or undetectable levels of unspliced or singly-spliced mRNA in PBMC from FIV-B infected cats. The larger mRNA species, and production of infectious virus, could be rapidly induced by mitogen treatment. This is in contrast to our findings for FIV-C, in which we observed only short, promoter-proximal transcripts [91], similar to what was reported for HIV latency in vivo [92]. We have quantified the latent reservoir in peripheral CD4+ T-cells during asymptomatic phase of FIV-C infection to be approximately one in $10^{5}$ cells ( 1 in $10^{3}$ cells is infected, but only 1:100 of those is replication competent), with just one provirus per infected cell [91]. This figure is similar to that of HIVinfected humans in the asymptomatic phase [93,94]. Lastly, Uckun et al. report outgrowth of infectious virus from PBMC of cats chronically infected (> 6 months) with FIV-A, B, and D upon co-culture with specific pathogen free (SPF) T-cell-enriched PBMC [95]. While this is suggestive of latency, measures of viremia or cellassociated vRNA were not reported. The specific memory phenotype of CD4+ T cells that serve as a reservoir for FIV is currently unknown, but this question is actively being pursued.

A number of studies have used in vitro and ex vivo models to study mechanisms of FIV latency. One group found a temperature-induced latency in Crandell-Rees feline kidney (CRFK) cells and feline PBMC incubated with FIV at $41^{\circ} \mathrm{C}$, which was reversible with return to the permissive temperature of $37^{\circ} \mathrm{C}$ [96]. Using methylcytosine mapping, our group found no evidence that proviral promoter CpG hypermethylation is associated with latency in peripheral CD4+ T cells or monocytes obtained from experimentally FIV-infected cats [97]. Though DNA methylation was originally implicated from in vitro studies of HIV latency [98,99], this association was not found in latently-infected, resting CD4+ T cells from HIV-infected individuals on ART [100], similar to our findings for FIV. We have, however, found an association between latency and a locally restrictive chromatin environment characterized by histone methylation and de-acetylation on lysine residues [91]. In the same study, we demonstrated that RNA polymerase II appeared to be paused on the latent FIV promoter, transcribing only short (between 66 and $118 \mathrm{bp})$ transcripts as mentioned above. This is especially interesting given the lack of a known tat-like function encoded by FIV. Histone modification (particularly acetylation) and resulting chromatin condensation is thought to be an important mechanism of latency in HIV [11,21,101-103]. A variety of pharmacologic inhibitors of histone deacetylase (HDAC) and histone methyltransferase (HMT) are able to reactivate latent FIV ex vivo [104], corroborating the link between FIV latency and chromatin status, and confirming that latent proviruses are capable of productive virus replication upon activation. There is substantial interest in the use of HDAC inhibitors, especially suberoylanilide hydroxamic acid (SAHA), for ALT in HIV infection [101,105-110]. Another group independently found that sodium butyrate $(\mathrm{NaB})$ was able to reactive a 
clonal in vitro model of FIV latency [88]. Although not identified as such in that report, $\mathrm{NaB}$ is a type of HDAC inhibitor. Finally, Chan et al. found that the protein kinase $\mathrm{C}$ (PKC)-activating phorbol ester Prostratin stimulated FIV replication in a feline CD4+ T-cell line depleted of IL-2 (which was otherwise nonproductive) [111]. This study suggests that PKC is important for FIV replication, and PKC-activators such as Prostratin may be useful in purging latent reservoirs. PKC activators have similarly been shown to reactivate latent HIV [112-115]. Taken together, observations regarding FIV latency reveal many similarities with the features and mechanisms of HIV-1 latency as summarized in Table 1.

\section{Conclusions}

FIV latency is a relatively new field, with a paucity of pertinent and published research on the topic, but it represents a novel and exciting model of HIV latency. FIV is known to support latent infection, both in vitro and in vivo, and many parallels have been drawn between FIV and HIV mechanisms of latency. Furthermore, many of the same drugs under investigation as potential ALT candidates for HIV have been shown to pharmacologically reactivate FIV as well. If the concept of induction therapy (reactivating latent virus to purge the reservoir) is to progress, use of an animal model of lentiviral latency will be critical to guide the research forward. Not only is latency reactivation potentially dangerous, but removing HAART from well-controlled patients may not be logistically or ethically feasible. Moreover, the dosage, timing, and sequence of ALT versus ART must be determined, and the potential for pharmacologically isolated anatomic reservoirs to reseed the latent population must be thoroughly examined. FIV may be particularly well-suited as a model of central nervous system reservoirs due to high viral loads in circulating monocytes and potential for latent microglial infection. FIV has advantages and disadvantages relative to other in vivo latency models as described above, but perhaps its most valuable property as a model at this early stage of ALT development is the level of natural control of the virus during the chronic phase of infection. Because viremia and cell-associated vRNA naturally progress to low or undetectable levels in peripheral lymphoid cells, the effect of reactivating agents can be extricated from ART-mediated suppression. Drug-related parameters such as efficacy, potency, and kinetics of the effect (reactivation), can therefore be more easily evaluated and "disentangled" in this animal model. In addition, since eradication strategies depend heavily on immune surveillance and effective killing of reactivated cells, it is possible (if not likely) that the compromised immune systems of infected individuals will need to be boosted in order to mount a sufficient response [116]. The extensive research into correlates of immune protection against FIV infection (including the existence of a commercial vaccine) are an additional advantage of this model [58]. In conclusion, FIV infection of the domestic cat signifies a relatively unexplored and under-recognized but potentially informative and valuable model for lentiviral latency and therapeutic reactivation in humans.

Table 1 Summary of the features of FIV and HIV-1 latency discussed in this review

\begin{tabular}{lcc}
\hline Feature & FIV & HIV-1 \\
\hline Latently infected peripheral CD4+ T cells per million, approximate & 10 & $1-10$ \\
Primary T cell reservoir & CD4+ T cells & Central memory CD4 + T cells \\
Viremia in chronic infection (untreated) & Undetectable to low & Low to moderate \\
Accessory genes & rev, vif, orf-A & rev, vif, tat, vpr, vpu, nef \\
Tat-like function & NO & YES \\
Paused RNA Polymerase II detected on LTR in vivo & YES & YES \\
Detection of short, promoter-proximal transcripts in vivo & YES & YES \\
Detection of multiply-spliced viral mRNA in vivo & NO & NO \\
Promoter associated histone modifications involved & Acetylation and methylation & (others unknown) \\
in chromatin control of latency & NO & Acetylation, methylation, phosphorylation \\
CpG methylation of latent proviral promoter in vivo & YES & NO \\
Transcriptional reactivation by HDAC inhibitors & YES & YES \\
Transcriptional reactivation by HMT inhibitors & Unknown & YES \\
Transcriptional reactivation by DNMT inhibitors & YES & NO \\
Transcriptional reactivation by PKC activators & YES
\end{tabular}




\section{Abbreviations}

AIDS: Acquired immunodeficiency syndrome; ALT: Antilatency therapy; ART: Antiretroviral therapy; DMNT: DNA methyltransferase; FAIDS: Feline acquired immunodeficiency syndrome; FIV: Feline immunodeficiency virus; HAART: Highly active antiretroviral therapy; HIV-1: Human immunodeficiency virus-1; HDAC: Histone deacetylase; HMT: Histone methyltransferase; NaB: Sodium butyrate; PBMC: Peripheral blood mononuclear cells; PCR: Polymerase chain reaction; PKC: Protein kinase C; SIV: Simian immunodeficiency virus; SPF: Specific pathogen free.

\section{Competing interests}

The authors declare that they have no competing interests.

\section{Authors' contributions}

SJM wrote the manuscript draft. BGM and EES edited all the manuscript drafts. All authors read and approved the final manuscript.

\section{Acknowledgements}

SJM is supported by NIH T32 training grant \#5T32AI060555. This work was funded, in part, by the Center for Companion Animal Health, School of Veterinary Medicine, University of California, Davis.

\section{Author details}

'Department of Pathology, Microbiology \& Immunology, School of Veterinary Medicine, University of California, Davis, 4206 Vet Med 3A, Davis, CA 95616, USA. 2Department of Medicine and Epidemiology, School of Veterinary Medicine, University of California, 3115 Tupper Hall, Davis, CA 95616, USA. ${ }^{3}$ VetMed PMI, 4206 VetMed 3A, One Shields Avenue, Davis, CA 95616-5270, USA.

Received: 26 April 2013 Accepted: 27 June 2013

Published: 6 July 2013

\section{References}

1. Global Fact Sheet. Www.UNAIDS.org.

2. Granich R, Crowley S, Vitoria M, Smyth C, Kahn JG, Bennett R, Lo YR, Souteyrand $Y$, Williams B: Highly active antiretroviral treatment as prevention of HIV transmission: review of scientific evidence and update. Curr Opin HIV AIDS 2010, 5:298-304.

3. Este JA, Cihlar T: Current status and challenges of antiretroviral research and therapy. Antiviral Res 2010, 85:25-33.

4. Kallings LO: The first postmodern pandemic: 25 years of HIV/ AIDS. J Intern Med 2008, 263:218-243.

5. Keedy KS, Margolis DM: Therapy for persistent HIV. Trends Pharmacol Sci 2010, 31:206-211.

6. Chun TW, Justement JS, Murray D, Hallahan CW, Maenza J, Collier AC, Sheth PM, Kaul R, Ostrowski M, Moir S, et al: Rebound of plasma viremia following cessation of antiretroviral therapy despite profoundly low levels of HIV reservoir: implications for eradication. AIDS 2010, 24:2803-2808.

7. Trono D, Van Lint C, Rouzioux C, Verdin E, Barre-Sinoussi F, Chun TW, Chomont N: HIV persistence and the prospect of long-term drug-free remissions for HIV-infected individuals. Science 2010, 329:174-180.

8. Joos B, Fischer M, Kuster H, Pillai SK, Wong JK, Boni J, Hirschel B, Weber R, Trkola A, Gunthard HF: HIV rebounds from latently infected cells, rather than from continuing low-level replication. Proc Natl Acad Sci U S A 2008 , 105:16725-16730.

9. Chomont N, El-Far M, Ancuta P, Trautmann L, Procopio FA, Yassine-Diab B, Boucher G, Boulassel MR, Ghattas G, Brenchley JM, et al: HIV reservoir size and persistence are driven by $T$ cell survival and homeostatic proliferation. Nat Med 2009, 15:893-900.

10. Murphy B, Vapniarsky N, Hillman C, Castillo D, McDonnel S, Moore P, Luciw PA, Sparger EE: FIV establishes a latent infection in feline peripheral blood CD4+ T lymphocytes in vivo during the asymptomatic phase of infection. Retrovirology 2012, 9:12.

11. Richman DD, Margolis DM, Delaney M, Greene WC, Hazuda D, Pomerantz RJ: The challenge of finding a cure for HIV infection. Science 2009, 323:1304-1307.

12. Dinoso JB, Rabi SA, Blankson JN, Gama L, Mankowski JL, Siliciano RF, Zink MC, Clements JE: A simian immunodeficiency virus-infected macaque model to study viral reservoirs that persist during highly active antiretroviral therapy. J Virol 2009, 83:9247-9257.

13. Chun TW, Fauci AS: HIV reservoirs: pathogenesis and obstacles to viral eradication and cure. AIDS 2012, 26:1261-1268.
14. Smith MZ, Wightman F, Lewin SR: HIV reservoirs and strategies for eradication. Curr HIV/AIDS Rep 2012, 9:5-15.

15. Yin H, Zhang $Y$, Zhou $X$, Zhu H: Histonedeacetylase inhibitor Oxamflatin increase HIV-1 transcription by inducing histone modification in latently infected cells. Mol Biol Rep 2010, 38(8):5071-5078.

16. Kim KC, Kim HG, Roh TY, Park J, Jung KM, Lee JS, Choi SY, Kim SS, Choi BS: The effect of CD4 receptor downregulation and its downstream signaling molecules on HIV-1 latency. Biochem Biophys Res Commun 2011, 404:646-651.

17. Yamagishi M, Ishida T, Miyake A, Cooper DA, Kelleher AD, Suzuki K, Watanabe $\mathrm{T}$ : Retroviral delivery of promoter-targeted shRNA induces long-term silencing of HIV-1 transcription. Microbes Infect 2009, 11:500-508.

18. Williams SA, Greene WC: Regulation of HIV-1 latency by T-cell activation. Cytokine 2007, 39:63-74.

19. Ikeda T, Shibata J, Yoshimura K, Koito A, Matsushita S: Recurrent HIV-1 integration at the $\mathrm{BACH} 2$ locus in resting $\mathrm{CD} 4+\mathrm{T}$ cell populations during effective highly active antiretroviral therapy. J Infect Dis 2007, 195:716-725.

20. Margolis DM: Mechanisms of HIV latency: an emerging picture of complexity. Curr HIV/AIDS Rep 2010, 7:37-43.

21. Colin L, Van Lint C: Molecular control of HIV-1 postintegration latency: implications for the development of new therapeutic strategies. Retrovirology 2009, 6:111.

22. Lenasi T, Contreras $X$, Peterlin BM: Transcriptional interference antagonizes proviral gene expression to promote HIV latency. Cell Host Microbe 2008, 4:123-133.

23. Pace MJ, Agosto L, Graf EH, O'Doherty U: HIV reservoirs and latency models. Virology 2011, 411:344-354

24. Tyagi M, Romerio F: Models of HIV-1 persistence in the CD4+ T cell compartment: past, present and future. Curr HIV Res 2011, 9:579-587.

25. Lassen KG, Hebbeler AM, Bhattacharyya D, Lobritz MA, Greene WC: A flexible model of HIV-1 latency permitting evaluation of many primary CD4 T-cell reservoirs. PLoS One 2012, 7:e30176.

26. Duyne RV, Narayanan A, K-Hall K, Saifuddin M, Shultz L, Kashanchi F: Humanized mouse models of HIV-1 latency. Curr HIV Res 2011, 9:595-605.

27. Clements JE, Gama L, Graham DR, Mankowski JL, Zink MC: A simian immunodeficiency virus macaque model of highly active antiretroviral treatment: viral latency in the periphery and the central nervous system. Curr Opin HIV AIDS 2011, 6:37-42.

28. Wongsrikeao P, Saenz D, Rinkoski T, Otoi T, Poeschla E: Antiviral restriction factor transgenesis in the domestic cat. Nat Methods 2011, 8:853-859.

29. Pedersen NC, Ho EW, Brown ML, Yamamoto JK: Isolation of a Tlymphotropic virus from domestic cats with an immunodeficiency-like syndrome. Science 1987, 235:790-793

30. Hayward JJ, Rodrigo AG: Molecular epidemiology of feline immunodeficiency virus in the domestic cat (Felis catus). Vet Immunol Immunopathol 2010, 134:68-74.

31. Kanzaki LI, Looney DJ: Feline immunodeficiency virus: a concise review. Front Biosci 2004, 9:370-377.

32. Burkhard MJ, Dean GA: Transmission and immunopathogenesis of FIV in cats as a model for HIV. Curr HIV Res 2003, 1:15-29.

33. Elder JH, Lin YC, Fink E, Grant CK: Feline immunodeficiency virus (FIV) as a model for study of lentivirus infections: parallels with HIV. Curr HIV Res 2010, 8:73-80

34. Sparger EE: FIV as a Model for HIV: An Overview. New York: Springer; 2006.

35. Hartmann K: Clinical aspects of feline retroviruses: a review. Viruses 2012, 4:2684-2710.

36. Yamamoto JK, Sparger E, Ho EW, Andersen PR, O'Connor TP, Mandell CP, Lowenstine L, Munn R, Pedersen NC: Pathogenesis of experimentally induced feline immunodeficiency virus infection in cats. Am J Vet Res 1988, 49:1246-1258

37. Kohmoto M, Uetsuka K, Ikeda Y, Inoshima Y, Shimojima M, Sato E, Inada G, Toyosaki T, Miyazawa T, Doi K, Mikami T: Eight-year observation and comparative study of specific pathogen-free cats experimentally infected with feline immunodeficiency virus (FIV) subtypes A and B: terminal acquired immunodeficiency syndrome in a cat infected with FIV petaluma strain. J Vet Med Sci 1998, 60:315-321.

38. Ackley CD, Yamamoto JK, Levy N, Pedersen NC, Cooper MD: Immunologic abnormalities in pathogen-free cats experimentally infected with feline immunodeficiency virus. J Virol 1990, 64:5652-5655.

39. Barlough JE, Ackley CD, George JW, Levy N, Acevedo R, Moore PF, Rideout BA, Cooper MD, Pedersen NC: Acquired immune dysfunction in cats with 
experimentally induced feline immunodeficiency virus infection: comparison of short-term and long-term infections. J Acquir Immune Defic Syndr 1991, 4:219-227

40. Gemeniano MC, Sawai ET, Leutenegger CM, Sparger EE: Feline immunodeficiency virus ORF-Ais required for virus particle formation and virus infectivity. J Virol 2003, 77:8819-8830.

41. Gemeniano MC, Sawai ET, Sparger EE: Feline immunodeficiency virus OrfA localizes to the nucleus and induces cell cycle arrest. Virology 2004, 325:167-174.

42. Chatterji $U$, de Parseval A, Elder JH: Feline immunodeficiency virus OrfA is distinct from other lentivirus transactivators. J Virol 2002, 76:9624-9634.

43. Dean GA, Reubel GH, Moore PF, Pedersen NC: Proviral burden and infection kinetics of feline immunodeficiency virus in lymphocyte subsets of blood and lymph node. J Virol 1996, 70:5165-5169.

44. Gulzar N, Copeland KF: CD8+ T-cells: function and response to HIV infection. Curr HIV Res 2004, 2:23-37.

45. Embretson J, Zupancic M, Beneke J, Till M, Wolinsky S, Ribas JL, Burke A, Haase AT: Analysis of human immunodeficiency virus-infected tissues by amplification and in situ hybridization reveals latent and permissive infections at single-cell resolution. Proc Natl Acad Sci U S A 1993, 90:357-361.

46. English RV, Johnson CM, Gebhard DH, Tompkins MB: In vivo lymphocyte tropism of feline immunodeficiency virus. J Virol 1993, 67:5175-5186.

47. Fritsch L, Marechal V, Schneider V, Barthet C, Rozenbaum W, Moisan-Coppey M, Coppey J, Nicolas JC: Production of HIV-1 by human B cells infected in vitro: characterization of an EBV genome-negative B cell line chronically synthetizing a low level of HIV-1 after infection. Virology 1998, 244:542-551.

48. Dow SW, Mathiason CK, Hoover EA: In vivo monocyte tropism of pathogenic feline immunodeficiency viruses. J Virol 1999, 73:6852-6861.

49. Dean GA, Himathongkham S, Sparger EE: Differential cell tropism of feline immunodeficiency virus molecular clones in vivo. J Virol 1999, 73:2596-2603.

50. Willett BJ, McMonagle EL, Ridha S, Hosie MJ: Differential utilization of CD134 as a functional receptor by diverse strains of feline immunodeficiency virus. J Virol 2006, 80:3386-3394.

51. Shimojima M, Miyazawa T, Ikeda Y, McMonagle EL, Haining H, Akashi $H$, Takeuchi Y, Hosie MJ, Willett BJ: Use of CD134 as a primary receptor by the feline immunodeficiency virus. Science 2004, 303:1192-1195.

52. Sattentau QJ, Dalgleish AG, Weiss RA, Beverley PC: Epitopes of the CD4 antigen and HIV infection. Science 1986, 234:1120-1123.

53. de Parseval A, Chatterji U, Sun P, Elder JH: Feline immunodeficiency virus targets activated CD4+ T cells by using CD134 as a binding receptor. Proc Natl Acad Sci U S A 2004, 101:13044-13049.

54. Gorry PR, Ancuta P: Coreceptors and HIV-1 pathogenesis. Curr HIV/AIDS Rep 2011, 8:45-53.

55. Poeschla EM, Looney DJ: CXCR4 is required by a nonprimate lentivirus: heterologous expression of feline immunodeficiency virus in human, rodent, and feline cells. J Virol 1998, 72:6858-6866.

56. Broder CC, Collman RG: Chemokine receptors and HIV. J Leukoc Biol 1997 62:20-29.

57. Brelot A, Heveker N, Adema K, Hosie MJ, Willett B, Alizon M: Effect of mutations in the second extracellular loop of CXCR4 on its utilization by human and feline immunodeficiency viruses. J Virol 1999, 73:2576-2586.

58. Yamamoto JK, Sanou MP, Abbott JR, Coleman JK: Feline immunodeficiency virus model for designing HIV/AIDS vaccines. Curr HIV Res 2010, 8:14-25.

59. Goto $Y$, Nishimura $Y$, Baba K, Mizuno T, Endo Y, Masuda K, Ohno K, Tsujimoto H: Association of plasma viral RNA load with prognosis in cats naturally infected with feline immunodeficiency virus. J Virol 2002, 76:10079-10083.

60. Diehl L, Mathiason-DuBard CK, O'Neil LL, Hoover EA: Longitudinal assessment of feline immunodeficiency virus kinetics in plasma by use of a quantitative competitive reverse transcriptase PCR. J Virol 1995, 69:2328-2332

61. Diehl L, Mathiason-Dubard CK, O'Neil LL, Obert LA, Hoover EA: Induction of accelerated feline immunodeficiency virus disease by acute-phase virus passage. J Virol 1995, 69:6149-6157.

62. Diehl LJ, Mathiason-Dubard CK, O'Neil LL, Hoover EA: Plasma viral RNA load predicts disease progression in accelerated feline immunodeficiency virus infection. J Virol 1996, 70:2503-2507.

63. Miller MM, Fogle JE: Administration of Fozivudine tidoxil as a single-agent therapeutic during acute feline immunodeficiency virus infection does not alter chronic infection. Viruses 2012, 4:954-962.
64. Miller C, Bielefeldt-Ohmann H, MacMillan M, Huitron-Resendiz S, Henriksen S, Elder J, VandeWoude S: Strain-specific viral distribution and neuropathology of feline immunodeficiency virus. Vet Immunol Immunopathol 2011, 143:282-291.

65. Freer G, Matteucci D, Mazzetti P, Tarabella F, Ricci E, Bozzacco L, Merico A, Pistello M, Ceccherini-Nelli L, Bendinelli M: Immunotherapy with internally inactivated virus loaded dendritic cells boosts cellular immunity but does not affect feline immunodeficiency virus infection course. Retrovirology 2008, 5:33.

66. Kraase M, Sloan R, Klein D, Logan N, McMonagle L, Biek R, Willett BJ, Hosie MJ: Feline immunodeficiency virus env gene evolution in experimentally infected cats. Vet Immunol Immunopathol 2010, 134:96-106.

67. Giannecchini S, Pistello M, Isola P, Matteucci D, Mazzetti P, Freer G, Bendinelli M: Role of Env in resistance of feline immunodeficiency virus (FIV)-infected cats to superinfection by a second FIV strain as determined by using a chimeric virus. J Virol 2007, 81:10474-10485.

68. Pistello M, Matteucci D, Cammarota G, Mazzetti P, Giannecchini S, Del Mauro D, Macchi S, Zaccaro L, Bendinelli M: Kinetics of replication of a partially attenuated virus and of the challenge virus during a three-year intersubtype feline immunodeficiency virus superinfection experiment in cats. J Virol 1999, 73:1518-1527.

69. English RV, Nelson P, Johnson CM, Nasisse M, Tompkins WA, Tompkins MB: Development of clinical disease in cats experimentally infected with feline immunodeficiency virus. J Infect Dis 1994, 170:543-552.

70. Hofmann-Lehmann R, Holznagel E, Ossent P, Lutz H: Parameters of disease progression in long-term experimental feline retrovirus (feline immunodeficiency virus and feline leukemia virus) infections: hematology, clinical chemistry, and lymphocyte subsets. Clin Diagn Lab Immunol 1997, 4:33-42

71. Callanan JJ, Racz P, Thompson H, Jarrett O: Lymph node pathology in experimental FIV infection. Adv Exp Med Biol 1994, 355:169-175.

72. Poli A, Abramo F, Di lorio C, Cantile C, Carli MA, Pollera C, Vago L, Tosoni A, Costanzi G: Neuropathology in cats experimentally infected with feline immunodeficiency virus: a morphological, immunocytochemical and morphometric study. J Neurovirol 1997, 3:361-368.

73. Poli A, Tozon N, Guidi G, Pistello M: Renal alterations in feline immunodeficiency virus (FIV)-infected cats: a natural model of lentivirusinduced renal disease changes. Viruses 2012, 4:1372-1389.

74. Mandell C, Sparger EE, Pedersen NC, Jain NC: Long-term haematological changes in cats experimentally infected with feline immunodeficiency virus (FIV). Comp Haematol Int 1992, 2:8-17.

75. Torten M, Franchini M, Barlough JE, George JW, Mozes E, Lutz H, Pedersen NC: Progressive immune dysfunction in cats experimentally infected with feline immunodeficiency virus. J Virol 1991, 65:2225-2230.

76. Lehmann R, von Beust B, Niederer E, Condrau MA, Fierz W, Aubert A, Ackley CD, Cooper MD, Tompkins MB, Lutz H: Immunization-induced decrease of the CD4+:CD8+ ratio in cats experimentally infected with feline immunodeficiency virus. Vet Immunol Immunopathol 1992, 35:199-214.

77. Tompkins MB, Tompkins WA: Lentivirus-induced immune dysregulation. Vet Immunol Immunopathol 2008, 123:45-55.

78. Vahlenkamp TW, Tompkins MB, Tompkins WA: Feline immunodeficiency virus infection phenotypically and functionally activates immunosuppressive CD4 + CD25+ T regulatory cells. J Immuno/ 2004, 172:4752-4761.

79. Beatty JA, Willett BJ, Gault EA, Jarrett O: A longitudinal study of feline immunodeficiency virus-specific cytotoxic T lymphocytes in experimentally infected cats, using antigen-specific induction. J Virol 1996, 70:6199-6206.

80. Joshi A, Vahlenkamp TW, Garg H, Tompkins WA, Tompkins MB: Preferential replication of FIV in activated CD4(+)CD25(+)T cells independent of cellular proliferation. Virology 2004, 321:307-322.

81. Joshi A, Garg H, Tompkins MB, Tompkins WA: Preferential feline immunodeficiency virus (FIV) infection of CD4+ CD25+ T-regulatory cells correlates both with surface expression of CXCR4 and activation of FIV long terminal repeat binding cellular transcriptional factors. J Virol 2005 , 79:4965-4976.

82. Lankford S, Petty C, LaVoy A, Reckling S, Tompkins W, Dean GA: Cloning of feline FOXP3 and detection of expression in CD4 + CD25+ regulatory T cells. Vet Immunol Immunopathol 2008, 122:159-166.

83. Smithberg SR, Fogle JE, Mexas AM, Reckling SK, Lankford SM, Tompkins MB, Dean GA: In vivo depletion of CD4 + CD25+ regulatory T cells in cats. $\mathrm{J}$ Immunol Methods 2008, 329:81-91. 
84. Redmond WL, Ruby CE, Weinberg AD: The role of OX40-mediated co-stimulation in T-cell activation and survival. Crit Rev Immunol 2009, 29:187-201

85. Joshi A, Garg H, Tompkins MB, Tompkins WA: Different thresholds of T cell activation regulate FIV infection of CD4 + CD25+ and CD4 + CD25- cells. Virology 2005, 335:212-221.

86. Mikkelsen SR, Reckling SK, Egan EA, Dean GA: In vivo depletion of CD4(+) CD25(hi) regulatory $T$ cells is associated with improved antiviral responses in cats chronically infected with feline immunodeficiency virus. Virology 2010, 403:163-172.

87. Ikeda $Y$, Tomonaga $K$, Kawaguchi $Y$, Kohmoto M, Inoshima $Y$, Tohya $Y$, Miyazawa T, Kai C, Mikami T: Feline immunodeficiency virus can infect a human cell line (MOLT-4) but establishes a state of latency in the cells. J Gen Virol 1996, 77(Pt 8):1623-1630.

88. Tochikura TS, Naito Y, Kozutsumi Y, Hohdatsu T: Induction of feline immunodeficiency virus from a chronically infected feline T-lymphocyte cell line. Res Vet Sci 2012, 92:327-332.

89. Assogba BD, Leavell S, Porter K, Burkhard MJ: Mucosal administration of low-dose cell-associated feline immunodeficiency virus promotes viral latency. J Infect Dis 2007, 195:1184-1188.

90. Tomonaga $K$, Inoshima Y, Ikeda Y, Mikami T: Temporal patterns of feline immunodeficiency virus transcripts in peripheral blood cells during the latent stage of infection. J Gen Virol 1995, 76(Pt 9):2193-2204.

91. McDonnel SJ, Sparger EE, Luciw PA, Murphy BG: Transcriptional Regulation of Latent Feline Immunodeficiency Virus in Peripheral CD4+ T-lymphocytes. Viruses 2012, 4:878-888

92. Lin X, Irwin D, Kanazawa S, Huang L, Romeo J, Yen TS, Peterlin BM: Transcriptional profiles of latent human immunodeficiency virus in infected individuals: effects of Tat on the host and reservoir. J Virol 2003, 77:8227-8236

93. Chun TW, Carruth L, Finzi D, Shen X, DiGiuseppe JA, Taylor H, Hermankova M, Chadwick K, Margolick J, Quinn TC, et al: Quantification of latent tissue reservoirs and total body viral load in HIV-1 infection. Nature 1997, 387:183-188.

94. Josefsson L, King MS, Makitalo B, Brannstrom J, Shao W, Maldarelli F, Kearney MF, Hu WS, Chen J, Gaines H, et al: Majority of CD4+ T cells from peripheral blood of HIV-1-infected individuals contain only one HIV DNA molecule. Proc Natl Acad Sci U S A 2011, 108:11199-11204.

95. Uckun FM, Chen CL, Samuel P, Pendergrass S, Venkatachalam TK, Waurzyniak B, Qazi S: In vivo antiretroviral activity of stampidine in chronically feline immunodeficiency virus-infected cats. Antimicrob Agents Chemother 2003, 47:1233-1240.

96. Alix C, Martin JP, Braunwald J: Temperature sensitivity of two different steps in the viral life cycle of feline immunodeficiency virus. Virology 1999, 253:309-318.

97. Murphy B, Hillman C, Mok M, Vapniarsky N: Lentiviral latency in peripheral CD4+ T cells isolated from feline immunodeficiency virus-infected cats during the asymptomatic phase is not associated with hypermethylation of the proviral promoter. Virus Res 2012, 169:117-126.

98. Blazkova J, Trejbalova K, Gondois-Rey F, Halfon P, Philibert P, Guiguen A, Verdin E, Olive D, Van Lint C, Hejnar J, Hirsch I: CpG methylation controls reactivation of HIV from latency. PLOS Pathog 2009, 5:e1000554.

99. Kauder SE, Bosque A, Lindqvist A, Planelles V, Verdin E: Epigenetic regulation of HIV-1 latency by cytosine methylation. PLOS Pathog 2009, 5:e1000495.

100. Blazkova J, Murray D, Justement JS, Funk EK, Nelson AK, Moir S, Chun TW, Fauci AS: Paucity of HIV DNA methylation in latently infected, resting CD4+ $T$ cells from infected individuals receiving antiretroviral therapy. J Virol 2012, 86:5390-5392.

101. Margolis DM: Histone deacetylase inhibitors and HIV latency. Curr Opin HIV AIDS 2011, 6:25-29.

102. Taube R, Peterlin M: Lost in transcription: molecular mechanisms that control HIV latency. Viruses 2013, 5:902-927.

103. Blankson JN, Persaud D, Siliciano RF: The challenge of viral reservoirs in HIV-1 infection. Annu Rev Med 2002, 53:557-593.

104. McDonnel SJ, Sparger EE, Luciw PA, Murphy BG: Pharmacologic reactivation of latent feline immunodeficiency virus ex vivo in peripheral CD4+ T-lymphocytes. Virus Res 2012, 170:174-179.

105. Wightman F, Ellenberg P, Churchill M, Lewin SR: HDAC inhibitors in HIV. Immunol Cell Biol 2012, 90:47-54.
106. Huber K, Doyon G, Plaks J, Fyne E, Mellors JW, Sluis-Cremer N: Inhibitors of histone deacetylases: correlation between isoform specificity and reactivation of HIV type 1 (HIV-1) from latently infected cells. J Biol Chem 2011, 286:22211-22218.

107. Contreras X, Schweneker M, Chen CS, McCune JM, Deeks SG, Martin J, Peterlin BM: Suberoylanilide hydroxamic acid reactivates HIV from latently infected cells. J Biol Chem 2009, 284:6782-6789.

108. Archin NM, Espeseth A, Parker D, Cheema M, Hazuda D, Margolis DM: Expression of latent HIV induced by the potent HDAC inhibitor suberoylanilide hydroxamic acid. AIDS Res Hum Retroviruses 2009, 25:207-212.

109. Ylisastigui L, Archin NM, Lehrman G, Bosch RJ, Margolis DM: Coaxing HIV-1 from resting CD4 T cells: histone deacetylase inhibition allows latent viral expression. AIDS 2004, 18:1101-1108.

110. Archin NM, Liberty AL, Kashuba AD, Choudhary SK, Kuruc JD, Crooks AM, Parker DC, Anderson EM, Kearney MF, Strain MC, et al: Administration of vorinostat disrupts HIV-1 latency in patients on antiretroviral therapy. Nature 2012, 487:482-485.

111. Chan CN, McMonagle EL, Hosie MJ, Willett BJ: Prostratin exhibits both replication enhancing and inhibiting effects on FIV infection of feline CD4(+) T-cells. Virus Res 2013, 171:121-128.

112. Sanchez-Duffhues G, Vo MQ, Perez M, Calzado MA, Moreno S, Appendino G, Munoz E: Activation of latent HIV-1 expression by protein kinase $C$ agonists. A novel therapeutic approach to eradicate HIV-1 reservoirs. Curr Drug Targets 2011, 12:348-356.

113. Reuse S, Calao M, Kabeya K, Guiguen A, Gatot JS, Quivy V, Vanhulle C, Lamine A, Vaira D, Demonte D, et al: Synergistic activation of HIV-1 expression by deacetylase inhibitors and prostratin: implications for treatment of latent infection. PLoS One 2009, 4:e6093.

114. Hezareh M: Prostratin as a new therapeutic agent targeting HIV viral reservoirs. Drug News Perspect 2005, 18:496-500

115. Biancotto A, Grivel JC, Gondois-Rey F, Bettendroffer L, Vigne R, Brown S, Margolis LB, Hirsch I: Dual role of prostratin in inhibition of infection and reactivation of human immunodeficiency virus from latency in primary blood lymphocytes and lymphoid tissue. J Virol 2004, 78:10507-10515.

116. Shan L, Deng K, Shroff NS, Durand CM, Rabi SA, Yang HC, Zhang H, Margolick JB, Blankson JN, Siliciano RF: Stimulation of HIV-1-specific cytolytic T lymphocytes facilitates elimination of latent viral reservoir after virus reactivation. Immunity 2012, 36:491-501.

doi:10.1186/1742-4690-10-69

Cite this article as: McDonnel et al.: Feline immunodeficiency virus latency. Retrovirology 2013 10:69.

\section{Submit your next manuscript to BioMed Central and take full advantage of:}

- Convenient online submission

- Thorough peer review

- No space constraints or color figure charges

- Immediate publication on acceptance

- Inclusion in PubMed, CAS, Scopus and Google Scholar

- Research which is freely available for redistribution 